\title{
Pembelajaran Edutainment Dalam Penanaman Karakter Cinta Tanah Air Pada Anak Usia Dini di Sekolah Dasar
}

\author{
Elga Yanuardianto \\ Universitas Islam Jember \\ elgayanuardianto1987@gmail.com
}

\begin{abstract}
Abstrak
Konsep edutainment mencoba memadukan antara pendidikan dan hiburan, yang didalam konsep edutainment tersebut terdapat beberapa pendekatan yang lebih kita kenal sebagai SAVI (Somatik, Auditori, Visual dan Intelektual). Metode penelitian ini menggunakan jenis penelitian Library research, yaitu jenis penelitian yang dilakukan dan difokuskan pada penelaahan, pengkajian dan pembahasan literature-literatur, baik klasik maupun modern. Literature berbahsa arab, inggris, Indonesia dan sebagainya yang ada kaitannya dengan persoalan ini. Penelitian ini bersifat analisis deskriptif. Sumber data penelitian ini yaitu: Sumber primer dari pemikiran Beby De Poter. Sumber skunder meliputi: buku, artikel atau esai yang membahas konsep edutainment, dan buku yang berkenaan dengan konsep psikologi belajar anak, serta buku pendidikan karakter, terutama karakter cinta tanah air. Hasil penelitian ini menunjukkan: (1) Pembelajaran Edutainment Dalam Penanaman Karakter Cinta Tanah Air Bagi Anak Usia Dini Di Sekolah Dasar, yaitu: menumbuhkan karakter cinta tanah air, memunculkan emosi minat anak seperti rasa senang dan gembira dalam pembelajaran, guru dalam menyampaikan pembelajaran di kelas harus menunjukkan sikap kepedulian terhadap peserta didik. (2) Proses Penanaman Karakter Cinta Tanah Air Bagi Anak Usia Dini Di Sekolah Dasar, yaitu: proses pembelajaran interaksi antara siswa dan guru terbangun suasana menyenangkan, fleksibiltas guru dalam menyampaikan materi menyesuaikan dengan emosi peserta didik, hubungan keakraban dan persahabatan sebagaimana teman sendiri, dan guru memberikan kebabasan berexspresi kepada perserta didik pada saat proses pembelajaran.
\end{abstract}

Kata Kunci: Pembelajaran; Edutainment; Karakter Cinta Tanah Air 


\section{PENDAHULUAN}

Sejak usia dini rasa cinta terhadap tanah air harus sudah ditanamkan kepada anak di sekolah dasar, agar kelak mereka mampu menjadi generasi bangsa yang dapat mewujudkan sikap dan tingkah laku yang membangun masyarakat dalam mengakomudir kepentingan masyarakat serta menghidari prilaku penyimpangan sosial yang dapat merusak bahkan menghilangkan norma-norma dan nilai-nilai kebudayaan bangsa Indonesia. Guru sebagai pendidik memiliki tanggung jawab yang besar mewujudkannya, namun kenyataan menunjukkan banyak anak yang masih kurang faham tentang cinta tanah air, karena guru hanya menyampaikan pembelajaran yang seadanya tanpa melihat motivasi anak dalam belajar.

Proses pembelajaran di Indonesia hingga saat ini belum bisa memberikan kesempatan yang luas bagi peserta didik agar menikmati pembelajaran yang menyenangkan. Kekerasan dalam bidang pendidikan masih sering mewarnai pemberitaan di berbagai media, mulai media elektronik dan media massa. Hingga saat ini peserta didik masih menjadi objek eksploitasi, dengan anggapan bahwa mereka tidak lebih dari sekedar tubuh yang siap di isi pengetahuan kapan pun. Paradigma tersebut sebenarnya sudah tidak sesuai lagi dengan keadaan saat ini, ini sesuai dengan apa yang disampaikan oleh Bapak pendidikan nasional, Ki Hadjar D. bahwa tugas dari pendidik adalah membimbing dan mengawasi peserta didik, bahkan beliau melarang adanya kekerasan dalam proses pendidikan. Paradigma tentang pendidikan yang menyenangkan bagi peserta didik kembali menjadi tema yang menarik, namun harus digarisbawahi bahwa proses pendidikan harus tetap pada jalur yang tepat yaitu untuk mengantarkan peserta didik menemukan potensi dan mengembangkannya demi masa depan mereka. Tidak hanya menyenangkan, namun guru juga harus dapat menanamkan karakter cinta tanah air dengan menyisipkan tentang kepedulian anak kepada sesama, mencintai negaranya dengan saling menghargai. Karena dengan mengenalkan kepada anak mengenai berbagai 
macam suku, budaya, agama, ras dan golongan guru telah berperan dalam meningkatkan kesadaran anak akan nilai-nilai luhur budaya bangsa, sehingga membangkitkan semangat nasionalisme dan cinta tanh air.

Didalam Undang-undang dasar nomor 20 tahun 2003 pasal 3 tentang sistem pendidikan Nasional menjelaskan bahwa pendidikan nasional bertujuan untuk mengembangkan dan membentuk watak, karakter serta peradaban bangsa yang bermartabat dalam rangka mencerdaskan kehidupan bangsa. Dalam rumusan tujuan pendidikan tersebut dijelaskan bahwa tujuan pendidikan adalah menjadi dasar pengembangan pendidikan budaya dan karakter bangsa. Dan salah satu karakter yang harus ditanamkan oleh guru kepada peserta didik adalah karakter cinta tanah air. Sehingga butuh pendekatan pembelajaran yang kreatif dan menyenangkan agar tujuan pendidikan yang telah disebutkan diatas dapat tercapai dengan maksimal. Banyak cara untuk menciptakan suasana dan proses pembelajaran ${ }^{1}$ yang kreatif dan menyenangkan, salah satunya dengan munculnya konsep edutainment dalam dunia pendidikan pada saat ini yang mengkolaborasikan antara dua aktivitas (Pendidikan dan hiburan). Pembelajaran merupakan proses komunikasi dua arah, mengajar dilakukan oleh pihak guru sebagai pendidik, sedangkan belajar dilakukan oleh peserta didik mempelajari keterampilan dan pengetahuan tentang materi-materi pelajaran. Peserta didik belajar untuk mengembangkan kemampuan konseptual ilmu pengetahuan maupun mengembangkan kemampuan dan sikap pribadi yang dapat digunakan untuk mengembangkan dirinya. Dalam pembelajaran peserta sebagai subjek yang aktif melakukan proses berfikir, mencari, mengolah, mengurai, menggabungkan, menyimpulkan dan menyesuaikan masalah.

\section{METODE PENELITIAN}

Dalam proses penelitian ini peneliti menggunakan jenis penelitian Library research, yaitu jenis penelitian yang dilakukan dan difokuskan pada

\footnotetext{
1 Syaiful Sagala, Kemampuan Professional Guru Dan Kependidikan, (Bandung: Alfabeta, 2009), 164.
} 
penelaahan, pengkajian dan pembahasan literature-literatur, baik klasik maupun modern. Literature berbahsa arab, inggris, Indonesia dan sebagainya yang ada kaitannya dengan persoalan ini.

Penelitian ini bersifat analisis deskriptif, yaitu memberikan gambaran dan keterangan secara jelas, objektif, sistematis, analisis dan kritis terhadap suatu fenomena yang terjadi mengenain analisis tentang konsep Edutainment yang mampu membentuk karakter cinta tanah air kepada anak. Pendekatan ini didasari pada langkah awal dengan cara mengumpulkan data-data yang diperlukan dan kemudian dilanjutkan dengan mengkalsifikasi dan mendeskripsikannya. ${ }^{2}$ Sebagai penelitian kepustakaan, maka bahan-bahan kajian yang diambil atau digunakan sebagai sumbernya adalah: (a) Sumber primer adalah suatu refrensi yang dijadikan sumber utama acuan penelitian. Dalam penelitian ini, sumber primer yang digunakan adalah leteratur dari pemikiran Beby De Poter seperti buku Quantum Learning serta buku-buku yang menjelaskan tentang karakter budaya tanah air. (b) Bahan skunder meliputi: karya-karya tulis baik berupa buku, artikel atau esai yang membahas konsep edutainment, dan buku yang berkenaan dengan konsep psikologi belajar anak, serta buku pendidikan karakter, terutama karakter cinta tanah air.

\section{HASIL DAN PEMBAHASAN TEMUAN}

\section{Sejarah Edutainment}

Dalam sejarahnya Konsep belajar berwawasan edutainment telah diperkenalkan secara formal pada tahun 1980-an dan konsep edutainment telah menjadi metode pembelajaran yang sukses dan mampu membawa pengaruh yang besar dalam dunia pendidikan dan pelatihan di era milenium ini $^{3}$. Belajar yang menyenangkan, menurut konsep edutainment bisa dilakukan dengan menyelipkan humor dan permainan (game) ke dalam

\footnotetext{
${ }^{2}$ Lexy Moleong, Metodologi Penelitian Kualitatif, (Bandung: Remaja Rosda Karya, 2004), 105.

3 Hamruni. Edutainment dalam Pendidikan Islam dan Teori-teori Pembelajaran Quantum, (Yogyakarta: Fakultas Tarbiyah UIN Sunan Kalijaga, 2009), 51.
} 
proses pembelajaran tetapi bisa juga dengan cara yang lain, misalnya dengan menggunakan metode bermain peran (roleplay), demonstrasi dan multimedia. Tujuannya adalah agar pembelajar (murid) bisa mengikuti dan mengalami proses pembelajaran dalam suasana yang gembira, menyenangka ${ }^{4}$ menghibur dan mencedaskan.

Ada dua kualitas belajar yang harus dikembangkan dalam diri murid guna mewujudkan pembelajaran yang menyenangkan, terutama dalam menanamkan karakter cinta tanah air, yakni:

a) Belajar untuk menjadi (Learning to $B e$ ) akan menghasilkan pribadi yang mandiri. Sehingga dalam penanaman cintan tanah air dalam dunia pendidikan memiliki fungsi agar tertanam moral yang diharapkan dapat membentuk siswa menjadi warga negara yang baik.

b) Belajar untuk belajar (Learning to Learn) dengan terus-menerus secara aktif. Dengan menanamkan nilai-nilai cinta tanah air dan semangat kebangsaan melalui menyanyikan lagu kebangsaan, membaca pancasila dll semua dilakukan dalam pembelajaran secara terus menerus dan dalam suasana belajar yang menimbukan rasa senang. ${ }^{5}$

Dalam konsep edutainment setiap proses pembelajaran harus menyenangkan. Oleh sebab itulah, konsep edutainment menjadi salah satu terobosan dalam proses pembelajaran yang selama ini hanya dipahami sebagai proses belajar-mengajar di dalam kelas padahal proses belajar di luar kelas dapat memacu kreativitas anak didik. ${ }^{6}$

Pada musim gugur 1981, Eric Jensen, Greg Simons dan Bobbi De

\footnotetext{
${ }^{4}$ Dave Meir memberikan pengertian menyenangkan atau fun sebagai suasana belajar dalam keadaan gembira. Susana gembira disini bukan berarti suasana ribut, hura-hura, kesenangan yang sembrono dan kemeriahan yang dangkal. Indrawati dan Wawan Setiawan, Pembelajaran Aktif, Kreatif, Efektif dan Menyenangkan, Untuk Guru SD(pdf), (Jakarta: PPPPTK IPA, 2009), 16.

${ }^{5}$ Tohirin MS, Psikologi Pembelajaran Pendidikan Agama Islam, (Jakarta: PT Raja Grafindo Persada, 2005), 77-78.

${ }^{6}$ Arief Rahman, Guru besar UNJ dalam seminar "Edutainment sebagai Sarana Pendukung Pendidikan Berbasis Kompetensi" pada tanggal 27 Mei 2009. diambil dari www.kompas.com pada tanggal 07 januari 2020.
} 
Porter berinisiatif untuk menciptakan program 10 hari yang menerapkan prinsip-prinsip belajar quantum, yakni dengan mengkombinasikan rasa percaya diri, keterampilan belajar dan kemampuan berkomunikasi dalam suatu lingkungan yang menyenangkan. Pada musim panas 1982, kelompok pertama yang terdiri 68 remaja tiba di perkemahan, yang mereka sebut dengan super camp. Pada awalnya, sebagian besar murid-murid itu merasa enggan, curiga dan tidak mau bekerja sama. Muncul kekhawatiran atas keberhasilan program ini tetapi setelah beberapa saat berjalan mulai terlihat trobosan mengagumkan yang menunjukkan bahwa program tersebut menuju kearah yang tepat. Akhirnya, program ini berhasil bahkan melebihi dari yang diharapkan dan menjadi peristiwa penting dalam kehidupan para remaja yang mengikutinya. ${ }^{7}$

\section{Hakikat Edutainment}

Dalam proses pembelajaran yang ideal sebuah interaksi tentunya menjadi proses penting yang harus diperhatikan dalam pembelajaran. Karena proses pembelajaran itu sendiri merupakan sebuah interaksi edukatif. Ada empat proses yang harus di perhatikan, Pertama, proses interaksi, seperti siswa berinteraksi secara aktif dengan guru, rekan siswa, multimedia, referensi, lingkungan dsb. Kedua, proses komunikasi, siswa mengkomunikasikan pengalaman belajar mereka dengan guru dan rekan siswa lain melalui cerita, dialog atau melalui simulasi role-play. Ketiga, proses refleksi, siswa memikirkan kembali tentang kebermaknaan apa yang mereka telah pelajari, dan apa yang mereka telah lakukan. Keempat, proses eksplorasi, siswa mengalami langsung dengan melibatkan semua indera mereka melalui pengamatan, percobaan, penyelidikan dan/atau wawancara. ${ }^{8}$

Dari beberapa proses tersebut, siswa sebagai peserta didik telah diposisikan sebagai subjek dalam proses pembelajaran, atau dengan kata

\footnotetext{
${ }^{7}$ Bobby De Porter dan Mike Hernacki, Quantum Learning: Membiasakan Belajar Nyaman dan Menyenangkan, terj. Alwiyah Abdurrahman (Bandung: Kaifa, 2002), 4-5. http://gurupkn.wordpress.com/2008/04/27/paradigma-baru-dalam-pendidikan-danpembelajaran-learning-is-fun/. Diakses tanggal 07 januari 2020
} 
lain siswa adalah sebuah unsur pokok dan sentral, bukan menjadi unsur pendukung dan tambahan. Dan pendidik sebagai pengajar tidak sepenuhnya mendominasi proses pembelajaran, pendidik berfungsi sebagai fasilitator sehingga membantu menciptakan suasana pembelajaran yang kondusif serta mampu memberikan motivasi dan bimbingan agar peserta didik dapat mengembangkan potensi dan kreatifitasnya melalui proses belajar di sekolah. ${ }^{9}$

Selain itu, di dalam proses pembelajaran, yang selalu terdiri dari 3 (tiga) komponen penting yang saling terkait satu sama lain, yaitu materi yang akan diajarkan, proses mengajarkan materi, dan hasil dari proses pembelajaran. 10 Dan dari ketiganya telah membentuk lingkungan pembelajaran. Namun dalam perjalanan prosesnya, sering ditemukan ketidakseimbangan dalam pembentukan lingkungan pembelajaran tersebut, salah satunya pada kuranganya pendekatan yang benar dan efektif dalam menjalankan proses pembelajaran. Sering kali kita temuai masih banyak pendidik yang masih focus pada materi dan hasil pembelajaran serta disibukkan dengan bnyaknya kegiatan untuk mencapai tujuan Pembelajaran yang ingin dicapai, merancang materi apa saja yang akan diajarkan serta merancang alat evaluasi. Dan hampir tidak pernah berfikir tentang bagaimana mendesain sebuah pembelajaran yang baik agar mampu menghubungkan materi dan hasil pembelajaran.

Eric Jensen telah mengunkapkan bahwa ada tiga unsur utama yang mempengaruhi belajar, unsur tersebut adalah keadaan, strategi, dan isi. Sehingga melahirkan suasana yang baik untuk proses belajar, penggunaan gaya atau metode presentasi yang baik dan benarserta topik pembelajaran yang diajarkan haruslah sesuai dengan kebutuhan. Sering kali terjadi sebuah proses pembelajaran hanya menaruh perhatian terhadap unsur yang kedua

\footnotetext{
9 Hamruni, Strategi dan Model-model Pembelajaran Aktif dan Menyenangkan, (Yogyakarta: Fakultas Tarbiyah Universitas Islam Negeri (UIN) Sunan Kalijaga, 2009), 41.

${ }^{10}$ Hamruni, Edutainment, 3.
} 
maupun unsur yang ketiga saja sehingga mengacuhkan unsur yang pertama, justru yang pertama akan menjadi kunci kesuksesan pada proses belajar itu sendiri. ${ }^{11}$ Dan belajar hanya akan efektif jika suasana (suasana hati peserta didik) berada dalam kondisi yang menyenangkan.

Lahirnya konsep edutainment, telah menjadikan proses pembelajaran menjadi kondusif dan menyenangkan, sehingga memunculkan suatu asumsi bahwa: pertama, perasaan positif (senang/gembira) akan mempercepat pembelajaran, kedua, jika seorang mampu menggunakan potensi nalar dan emosi secara jitu, maka ia akan membuat loncatan prestasi belajar yang tidak terduga sebelumnya, ketiga, bila setiap pembelajar dpat dimotivasi secara tepat dan diajar dengan cara yang benar, cara yang menghargai gaya belajar dan modalitas mereka, mereka semua akan dapat mencapai hasil belajar yang optimal. ${ }^{12}$

Tidak ada yang memungkiri bahwa proses belajar mengajar yang menyenangkan merupakan impian dari setiap peserta didik. Karena dengan pembelajaran yang menyenangkan mampu meningkatkan motivasi belajar yang tinggi bagi pendidik dalam menghasilkan kualitas belajar yang baik. Faktor motivasi merupakan kunci utama dalam mencapai keberhasilan proses belajar. Seorang pendidik harus mampu memahami secara pasti mengapa seorang peserta didik memiliki berbagai macam motif dalam belajar. Ada empat kategori yang perlu diketahui oleh seorang guru yang baik terkait dengan motivasi "mengapa siswa belajar", yaitu (1) motivasi intrinsik (siswa belajar karena tertarik dengan tugas-tugas yang diberikan), (2) motivasi instrumental (siswa belajar karena akan menerima konsekuensi: reward atau punishment), (3) motivasi sosial (siswa belajar karena ide dan gagasannya ingin dihargai), dan (4) motivasi prestasi (siswa belajar karena ingin menunjukkan kepada orang lain bahwa dia mampu melakukan tugas

\footnotetext{
11 Ibid,

12 Ibid, 7-8.
} 
yang diberikan oleh gurunya). ${ }^{13}$

Dari permasalahan di atas, dapat dipahami bahwa hakekat edutainment adalah suatu proses pembelajaran yang menggabungkan antara pendidikan dan hiburan, sehingga melahirkan suatu desain pembelajaran yang kreatif, menyenangkan dan menarik minat peserta didik untuk belajar. pada dasarnya edutainment membantu dalam mencapai keberhasilan peserta didik, karena dalam pembelajaran terdapat usaha mengembalikan kondisi siswa sesuai dengan hakekat diri siswa sebagai manusia, dengan mempercayai bahwa setiap setiap terdapat potensi diri yang bisa ditumbuhkembangkan melalui proses pembelajaran yang dijalaninya. Dengan menumbuhkan motivasi intrinsik dalam setiap diri siswa sehingga mampu menggunakan modalitas belajar mereka dan menjadikannya sebagai manusia pembelajar yang berada pada suasana belajar yang gembira dan menyenangkan.

Motivasi bisa berfungsi sebagai pendorong usaha dalam pencapaian prestasi. Karena motivasi menjadi pendorong seseorang melakukan sesuatu. Hasil belajar yang baik tentu lahir karena adanya motivasi belajar yang baik. sehingga dengan adanya usaha yang tekun yang didasari adanya motivasi, akan membuat seseorang yang belajar tersebut akan dapat meraih prestasi yang baik. Intensitas motivasi seseorang peserta didik akan sangat menentukan tingkat pencapaian prestasi belajarnya. ${ }^{14}$

\section{Karakteristik Edutainment}

Beberapa prinsip yang menjadi karakteristik dari konsep edutainment, yakni:

1) konsep edutainment adalah suatu rangkaian pendekatan dalam pembelajaran untuk menjembatani jurang yang memisahkan antara proses mengajar dan proses belajar sehingga diharapkan bisa

\footnotetext{
13 http://gurupkn.wordpress.com/2008/04/27/paradigma-baru-dalam-pendidikan-danpembela jaran-learning-is-fun/. Diakses tanggal 07 januari 2020.

${ }^{14}$ Sardiman, A.M., Interaksi dan Motivasi Belajar Mengajar, cet. III (Jakarta: Rajawali Pers, 1990), 84
} 
meningkatkan hasil belajar. Konsep ini dirancang agar proses belajar mengajar dilakukan secara holistik dengan menggunakan pengetahuan yang berasal dari berbagai disiplin ilmu seperti pengetahuan tentang cara kerja otak dan memori, motivasi, konsep diri, emosi (perasaan), gaya belajar, kecerdasan majemuk, teknik memori, teknik membaca, teknik mencatat dan teknik belajar lainnya. ${ }^{15}$

2) Konsep dasar edutainment melahirkan sebuah pembelajaran yang berlangsung dalam suasana yang kondusif dan menyenangkan. Ada tiga asumsi yang menjadi landasannya, yakni:

a) Perasaan gembira

Suasana gembira akan mempengaruhi cara otak dalam memproses, menyimpan dan mengambil informasi dengan mudah. Dalam upaya menciptakan kondisi ini maka konsep edutainment mencoba memadukan pendidikan dan hiburan.

Seorang ibu mengeluh bahwa anaknya yang baru taman kanakkanak sudah dapat mengungkapkan bahwa dirinya stres. Jika dipikirpikir, anak-anak mendapatkan banyak tekanan, baik dari guru-guru di sekolah maupun orangtua dengan harapan-harapan yang terkadang kurang realistis demi terpenuhinya cita-cita orangtua yang dulu tidak berhasil dicapai.

Anak tidak bisa belajar efektif dalam keadaan stres. Belajar perlu dinikmati dan timbul dari perasaan suka serta nyaman tanpa paksaan. Untuk menciptakan lingkungan tanpa stres bagi anak, penting bagi orangtua agar rileks dan tidak menetapkan target atau menuntut anak melebihi kemampuannya.

Hasil penelitian menunjukkan bahwa ada perbedaan tuntutan dari orangtua dengan budaya yang berbeda. Orangtua dari budaya Jepang dan Cina menetapkan standar yang lebih tinggi terhadap

\footnotetext{
${ }^{15}$ Hamruni. Edutainment, 42-43.
} 
prestasi anak, mengevaluasi dengan ketat hasil yang diperoleh, dan mendorong anak untuk bekerja lebih keras. Sedangkan orangtua Amerika lebih menekankan kemampuan dasar (IQ) anak daripada kerja keras dalam mencapai prestasi akademik. Sebenarnya perlu bagi orangtua untuk merefleksi diri dan menjawab dengan jujur pertanyaan; “Apakah yang saya lakukan ini adalah untuk kepentingan anak saya atau untuk kepentingan diri saya sendiri?"

b) Mengembangkan emosi positif anak

Ketika suatu pelajaran melibatkan emosi positif yang kuat, umumnya pelajaran tersebut akan terekam dengan kuat pula dalam ingatan. Oleh karena itu, dibutuhkan kreatifitas guru dan orangtua untuk menciptakan permainan-permainan yang dapat menjadi wadah dan sarana anak untuk belajar, misalnya melalui drama, warna, humor, dan lain-lain.

c) Optimalisasi potensi nalar anak secara jitu akan mampu membuat loncatan prestasi belajar secara berlipat ganda

Bagian neokorteks ${ }^{16}$ dari otak terbagi dalam beberapa fungsi khusus seperti fungsi berbicara, mendengar, melihat dan meraba. Jika ingin memiliki memori yang kuat maka informasi harus disimpan dengan menggunakan semua indera melihat, mendengar, berbicara, menyentuh, dan membaui. Anak-anak umumnya belajar melalui pengalaman konkret yang aktif. Untuk memahami konsep 'bulat'yang abstrak, seorang anak perlu bersentuhan langsung dengan bendabenda bulat, apakah itu dengan cara melihat dan meraba benda bulat atau dengan cara menggelindingkan bola.

\footnotetext{
${ }^{16}$ Neokorteks (proencephalon atau forebrain atau otak depan) yang terbungkus di sekitar bagian atas dan sisi-sisi limbik, yang mengisi $80 \%$ dari seluruh materi otak, adalah tempat kecerdasan yang mengatur pesan-pesan yang diterima melalui indera penglihatan, pendengaran dan sensasi tubuh, yang menimbulkan proses penalaran, berfikir intelektual, pembuatan keputusan, perilaku waras, bahasa, kendali motorik sadar dan indeasi (penciptaan gagasan) nonverbal.. Boby De Porteter dan Mike Hernack, Quantum Learning Membiaskan Belajar Nyaman dan Menyenangkan, terjemahan Alwiyah Abdurrahman, (Bandung: Kaifa, 2003). 28-30
} 
Menurut Vernon A. Magnesen dalam Quantum Teaching, belajar $10 \%$ dari apa yang kita baca; $20 \%$ dari apa yang didengar; $30 \%$ dari apa yang dilihat; 50\% dari apa yang dilihat dan dengar; 70\% dari apa yang dikatakan; dan 90\% dari apa yang dikatakan dan lakukan. ${ }^{17}$

d) Anak didik yang dimotivasi dengan tepat dan diajar dengan cara yang benar (cara yang yang menghargai gaya atau style dan keinginan mereka) maka mereka semua dapat mencapai suatu hasil belajar yang optimal. Pendekatan yang digunakan dalam konsep ini adalah anak didik akan diperkenalkan dengan cara dan proses belajar yang benar sesuai dengan kepribadian dan keunikan mereka masing-masing.

Menurut Nasution mengajar dikatakan berhasil jika anak-anak belajar sebagai akibat usaha itu. Oleh karena itu dalam proses pembelajaran yang meliputi proses pengajaran dan pengelolaan kelas tujuan utamanya adalah bagaimana mengupayakan agar anak didik dapat belajar. Agar murid mau belajar perlu diciptakan situasi belajar yang kondusif.

\section{Pendekatan Dalam Pembelajaran Edutainment}

Terdapat beberapa pendekatan belajar dalam metode pembelajaran edutainment, yaitu Somatik, Auditori, Visual dan Intelektual atau lebih dikenal dengan istilah SAVI. Agar berlangsung optimal keempatnya harus ada dalam pembelajaran. Karena unsur-unsur ini semuanya berkesinambungan, pembelajaran yang paling baik bisa berlangsung jika seluruhnya itu berjalan secara bersamaan. Adapun dalam pengelolaan dengan menggunakan cara belajar SAVI ini, yaitu: ${ }^{18}$

\section{Cara Belajar Somatic}

Istilah "Somatic" berasal dari bahasa Yunani yang berarti tubuh (soma). Jadi, belajar somatic adalah belajar melalui indra peraba, Anesthetic, praktis yang melibatkan fisik dan menggunakan serta menggerakkan tubuh

\footnotetext{
${ }^{17}$ www.batikyogya.wordpress.com diakses pada tanggal 07 Januari 2020.

${ }^{18} \mathrm{http}$ ://cakheppy.wordperss.com/2011/04/09/metode-edutainment/. Diakses tanggal 07 Januari 2020.
} 
sewaktu belajar. Atau dikenal dengan istilah Kinesthetic (gerakan). Somatic disini juga dinamakan dengan learning by moving and doing (belajar dengan belajar dan bergerak) jadi cara belajar somatic adalah pola pembelajaran yang lebih menekankan pada aspek gerak tubuh atau belajar dengan melakukan.

Aktivitas belajar Somatic melibatkan aktivitas fisik. Duduk terlalu lama, di dalam kelas ataupun di depan komputer akan mampu menghasilkan tenaga. namun jika berdiri, bergerak kesana kemari, dan melakukan kegiatan secara fisik dari waktu ke waktu akan mengaktifkan seluruh tubuh, memperbaiki sirkulasi otak dan membangkitkan pembelajaran.

\section{Cara Belajar Auditori}

Learning By Talking And Learning adalah belajar berbicara dan mendengarkan atau dikenal dengan istilah Auditori. Jadi belajar auditif merupakn suatu cara belajar yang menekankan pada aspek pendengaran. Peserta didik akan cepat paham jika materi yang disampaikan baik dengan ceramah atau alat yang dapat didengar.

Pikiran Auditori yang ada akan lebih kuat dari pada yang kita sadari. Telinga kita akan selalu menangkap dan menyimpan informasi Auditori, bahkan tanpa kita sadari. Dan sewaktu kita menghasulkan suara sendiri dengan berbicara, akan mengaktifkan beberapa area penting di otak kita.

Dalam merancang pelajaran yang menarik bagi seluruh auditori yang kuat dalam diri siswa, maka usahakan mencari cara untuk mengajak mereka membicarakan apa yang sedang mereka pelajari. Suruh mereka menterjemahkan pengalaman mereka dengan suara, atau dengan membaca keras-keras secara dramatis. Dengan cara ini setidaknya siswa lebih mudah mengingat dan dapat belajar dengan cepat jika materinya disampaikan secara belajar auditori. Karena dengan belajar auditori dapat merangsang kortes (selaput otak), indera dan motor (serta area otak lainnya) untuk memadatkan dan mengintegrasikan pembelajar (siswa). 


\section{Cara Belajar Visual}

Istilah Visual disini di definisikan sebagai belajar melalui mengamati dan menggambarkan atau disebut sebagai istilah Learning By Observing And Picturing. Adapun cara belajar visual ini adalah cara belajar yang menekankan pada aspek indra penglihatan. siswa akan dengan mudah menangkap materi pelajaran apabila disampaikan melalui tulisan atau gambar.

Di dalam otak terdapat lebih banyak perangkat dalam memproses sebuah informasi visual bila dibandingkan dengan semua indera yang lain, dari penjelasan tersebut dapat kita ketahui bahwa ketajaman visual sangat kuat dalam setiap diri seseorang. Fakta yang terjadi orang-orang yang melakukan pencitraan (simbol) dalam memahami teknis dan ilmiah mendapatkan nilai $12 \%$ tentu ini lebih baik untuk ingatan jangka pendek bila dibanding dengan mereka yang tidak menggunakan pencitraan, dan $2 \%$ lebih baik dalam ingatan jangka panjang. Ini semua berlaku bagi setiap orang tanpa memandang usia, etnis, gender atau gaya belajar yang dipilih.

dalam pembelajaran secara visual ini mencakup melihat, menciptakan dan mengintegrasikan segala macam citra komunikasi visual lebih kuat dari pada komunikasi verbal karena manusia mempunyai lebih banyak peralatan di kepala mereka untuk memproses informasi visual dari pada indera lainnya.

\section{Cara belajar intelektual}

Istilah intelektual merupakan sesuatu yang di aplikasikan pembelajaran dalam internal pikiran mereka, intelektual menggunakan kecerdasan dalam merenungkan suatu pengalaman dan menciptakan hubungan antara makna, nilai, dan pengalaman tersebut, sehingga mencipta, merenung, memecahkan masalah dan membangun diri merupakan bagian diri yang dilakukan intelektual.

Learning By Program And Reflecting juga disebut sebagai intelektual maksudnya adalah belajar melalui pemecahan masalah. sehingga cara 
belajar yang lebih menekankan pada aspek penalaran atau logika merupakn cara belajar intelektual. Dengan pembelajaran yang dirancang dengan menekankan aspek solusi pemecahan tentu peserta didik akan cepat memahami materi.

Jika dalam pelatihan belajar sisi intelektual belajar dilibatkan maka kebanyakan orang dapat menerima pelatihan yang banyak memasuki unsur bermain, tanpa merasa pelatihan tersebut dangkal, kekanak-kanakan atau hambar.

Kesimpulannya belajar akan optimal apabila keempat unsur SAVI (Somatic, Auditori, Visual dan Intelektual) diaplikasikan dalam suatu proses pembelajaran. Sehingga dalam pembelajaran eduataiment sangat dibutuhkan pendekatan SAVI, agar proses pembelajaran yang baik dapat berjalan dan mampu meningkatkan pembelajaran pada semua siswa.

\section{Pembelajaran Edutainment dalam Penanaman Karakter Cinta Tanah Air Pada Anak Usia Dini di Sekolah Dasar}

Sering kali dalam proses pembelajaran pendidik dihadapkan pada berbagai kasus yang berkaitan dengan perkembanagn siswa. Guru harus memperhatikan perubahan-perubahan dan perkembangan yang terjadi pada peserta didik, karena dengan kejadian ini guru dapat memilih strategi pembelajaran dengan menyesuaikan karakteristik siswa yang terlibat dalam proses pembelajaran. ${ }^{19}$

Seorang guru dalam pembelajaran di kelas mempunyai beberapa peran tugas yang harus dilakukan, salah satunya dengan menciptakan sebuah pembelajaran yang bertujuan untuk menumbuhkan karakter cinta tanah air namun dan memunculkan emosi anak seperti rasa senang dan gembira dalam pembelajaran. bahkan lebih dari itu, guru dalam menyampaikan pembelajaran di kelas juga harus menunjukkan sikap peduli terhadap peserta didik.

\footnotetext{
183.

${ }^{19}$ Syamsul Yusuf, Psikologi Perkembangan Anak dan Remaja. (Bandung: Rosda, 2014),
} 
Perilaku siswa didalam kelas terkontruksi oleh hal-hal pokok seperti minat, rasa ingin tahu (kurositas), keterikatan, dan motivasi intrinsic yang kesemuanya berimplikasi kepada keterlibatan siswa secara aktif dalam pembelajaran serta kemampuan pemahaman siswa terhadap bahan ajar. Dengan adanya minat dari peserta didik dalam pembelajaran akan berdampak besar terhadap sikap dan perilaku siswa dalam pembelajaran ataupun kegiatan disekolah. Karena minat berperan sangat penting dalam proses pembelajaran, sehingga siswa yang memiliki minat besar dalam proses pembelajaran tentu akan berusaha lebih giat dalam pembelajaran dibandingkan mereka yang kurang ataupun tidak berminat sama sekali.

Dalam hubungan ini ciri-ciri siswa yang berminat dalam belajar adalah sebagai berikut:

1. Memiliki kecendrungan untuk tetap antusias dan mengingat materi yang telah dipelajari secara terus menerus.

2. Akan ada rasa suka dan senang pada sesuatu yang diminati

3. Memiliki rasa keterkaitan terhadap suatu aktivitas yang diminati, sehingga memperoleh rasa bangga dan kepuasaan ketika menjalani sebuah aktivitas yang diminati tersebut

4. Lebih menyukai suatu hal yang menjadi minatnya dari pada yang lainnya.

5. Dimanifestasikan melalui partisipasi pada aktivitas dan kegiatan. ${ }^{20}$

Proses penanaman nilai-nilai cinta tanah air dalam pembelajaran dapat dilakukan melalui beberapa cara seperti: interaksi dalam proses pembelajaran antara siswa dan guru terbangun suasana menyenangkan, fleksibiltas guru dalam menyampaikan materi menyesuaikan dengan emosi peserta didik, hubungan keakraban dan persahabatan sebagaimana teman sendiri, dan guru memberikan kebabasan berexspresi kepada perserta didik pada saat proses pembelajaran, hal ini dapat dilakukan oleh guru dalam pendidikan sekolah dasar misalnya sekolah dasar (SD), dan madrasah

\footnotetext{
${ }^{20}$ Suyono. Implementasi Belajar dan Pembelajaran. (Bandung: Rosda, 2015), 176.
} 
ibtidaiyah MI) dimana dalam pembelajaran guru menyelipkan pesan-pesan tentang pentingnya mencitai tanah air dalam pembelajaran bagi anak. Seharusnya pembelajaran di kelas dapat dilakukan dengan menyenangkan ${ }^{21}$ bukan mendesain pembelajaran yang monoton dan membosankan sehingga membuat peserta didik tidak semangat dan tidak memiliki ketertarikan untuk mengikuti proses pembelajaran. Dengan demikian, suasana pembelajaran menjadi tidak kondusif dan siswa menjadi pasif. Sehingga jauh dari cita-cita pembelajaran yang dapat melahirkan siswa yang cerdas dan mampu mencintai tanah airnya.

Kemampuan berinovasi dan kreatifitas guru dalam memdesain suasana pembelajaran yang digunakan oleh guru sehingga dapat membentuk respon positif secara psikologis yaitu dengan ditunjukkan rasa antusiasme peserta didik terhadap proses pembelajaran. Hal demikian, dibutuhkan pendidik atau guru yang kreatif dan inovatif dalam pembelajaran, sehingga menjadikan proses belajar mengajar menjadi lebih menarik dan disukai oleh siswa, tentunya ini akan meningkatkan prestasi siswa dalam belajar. Penting untuk mendesain sebuah pembelajaran yang baik dengan merancang suasana kelas serta model pembelajaran yang tepat agar siswa mampu berinteraksi satu sama lain sehingga melahirkan siswa yang berprestasi yang nantinya mampu membangun bangsa dan negara dalam mengisi kemerdekaan yang telah diberikan Allah SWT. ${ }^{22}$

Dalam membentuk karakter dan mental generasi Indonesia yang berprestasi dan mencintai tanah airnya, sehingga nantinya akan terbentuk

\footnotetext{
${ }^{21}$ Kamin Sumardi, menyampaikan bahwa pembelajaran menyenangkan adalah ciri ke empat dari PAKEM mendesain pembelajaran dan dirancang untuk menghadirkan suasana kelas yang menyenangkan. Menyenangkan dalam artian pembelajaran tidak membelenggu, sehingga peserta didik mampu mengoptimalkan perhatiannya secara penuh pada pembelajaran, dengan demikian waktu untuk mencurahkan perhatian (time of task) siswa menjadi tinggi. Dengan demikian diharapkan siswa dapat meningkatkan hasil belajarnya. Kamin Sumardi, Pembelajaran Dengan Pendekatan Pakem (pdf). Disampaikan pada Seminar Nasional Creating Engaging Lesson (Menciptakan Pembelajaran yang membuat Siswa Terlibat secara Penuh) Cirebon, 14 Maret 2010

${ }^{22}$ Baharuddin. Pendidikan dan Psikologi Perkembangan, (Yogyakarta: Ar-Ruz Media, 2009), 197.
} 
generasi yang cerdas dan memiliki karakter cinta tanah air sesuai dengan tujuan pendidikan yang termaktub dalam UUD 1945. Dalam penerapan pembelajaran edutainment sebagai pendekatan yang digunakan dalam menanamkan karakter cinta tanah air di sekolah salah satu cara yang bisa digunakan guru adalah dengan mengajak siswa untuk belajar dekat dengan budaya local yang ada di sekitar kita, dan juga memahami sejarah kemerdekaan dan bagaimana mengisi kemerdekaan tersebut. Dengan mempelajari budaya local, memahami sejarah dan belajar mencintai bangsa ini tentu akan mengembangkan potensi yang dimiliki siswa dan dapat menumbuhkan karakter cinta tanah air. Penanaman karakter cinta tana air dengan pendekatan edutainment tentu akan mengajak siswa untuk belajar langsung dengan alam dan lingkungannya dengan rasa senang dan bahagia. Pengalaman dalam pembelajaran yang di dapat oleh siswa secara langsung dari lingkungan dalam suasana yang menyenangkan tentu akan memberikan dampak terhadap minat belajar dan tentunya meningkatkan efek positif terhadap hasil belajar siswa serta meningkatkan karakter cinta tanah air. ${ }^{23}$

Agar sebuah proses pembelajaran tidak terasa menjenuhkan dan membosankan dibutuhkan suasana belajar yang fun, enjoy dan menggembirakan. Seperti yang telah Frobel jelaskan penting menghadirkan permainan dalam belajar karena kegiatan bermain akan memudahkan anak dalam belajar, karena permainan akan selalu dinikmati dan dapat digunakan untuk menarik perhatian serta pengetahuan mereka dalam belajar. Banyak ahli seperti plato, Aristoteles serta Frobel beranggapan bahwa bermain akan menjadi sebuah aktivitas yang praktis. Artinya, media bermain dapat digunakan dalam meningkatkan keterampilan dan kemampuan anak. Bermain berfungsi sebagai perkembangan pribadi anak, serta mempunyai fungsi dalam social dam emosional anak.

\footnotetext{
${ }^{23}$ Sekar D A, Savitri W dan M Kanzunnudin, Implementasi Pembelajaran Berbasis Ethno-Edutainment Untuk Meningkatkan Karakter Cinta Tanah Air Siswa Sekolah Dasar. Jurnal Ilmiah Kependidikan, Vol. 9, No. 2 (2019), 204.
} 
Bermain adalah dunia anak. karena bermain akan menjadikan anakanak belajar berbagai macam hal. oleh karena itu dalam penanaman cinta tanah air dibutuhkan konsep penggabungkan antara belajar dan bermain, sehingga dengan bermain, akan banayak kemampuan dasar anak dikembangkan, seperti:

a. Mengembangkan kemampuan motorik melalui permainan: berjalan, berlari, melompat, meniti, melempar, menangkap, berdiri satu kaki, berjinjit, berguling dan sebagainya. Bisa menggunakan permainan yang mengandung unsur budaya, atau yang berkaitan tentang nilai-nilai cinta tanah air

b. Dalam menerapkan nilai-nilai cinta tanah air maka anak harus mengembangkan kemampuan bahasa dan daya pikir harus dikuasai. Agar anak mampu dan mudah dalam berkomunikasi dengan orang lain serta mampu memahami hal-hal yang ada sekitarnya. Dengan kemampuan bahasa dan daya pikir anak akan mengerti kewajibanya sebagai warga negara yang baik dan dapat menyampaikan kepada orang lain sesuatu yang telah difahaminya.

c. Dalam bergaul dengan orang lain anak harus mampu menguasai kemampuan dalam bermasyarakat atau berhubungan social agar anak dapat mandiri. Dengan cara orang tua dan pendidik memberikan kebebasan dalam melakukan kegiatan, dan menjawab semua yang ditanyakan oleh anak-anak. ${ }^{24}$

Dalam konsep pembelajaran edutainment, roh pembelajaran ada pada proses pembelajaran yang menyenangkan, nyaman dan mengagumkan serta ada pada bagaimana hubungan antara guru dan murid dapat terjalin dengan pendekatan dedaktik metodik yang bernuansa "Redagonis". Artinya “interaksi antara guru dan murid tidak dijalin dengan komunikasi yang kaku tetapi harmonis" seperti guru sangat luwes, akrab dan bersahabat

\footnotetext{
${ }^{24}$ Aunurrahman. Belajar dan Pembelajaran, (Bandung: Alfabeta, 2012), 58.
} 
sebagaimana teman sendiri. Dengan begitu siswa tidak merasa dibatasi, takut dan bisa berinteraksi dengan bebas dan menyenangkan.

\section{SIMPULAN}

Berdasarkan hasil analisis diatas, Pembelajaran edutainment dalam penanaman karakter cinta tanah air pada anak usia dini di sekolah dasar, yaitu: (1) Pembelajaran Edutainment Dalam Penanaman Karakter Cinta Tanah Air Bagi Anak Usia Dini Di Sekolah Dasar, yaitu: menumbuhkan karakter cinta tanah air, memunculkan emosi minat anak seperti rasa senang dan gembira dalam pembelajaran, guru dalam menyampaikan pembelajaran di kelas harus menunjukkan sikap kepedulian terhadap peserta didik. (2) Proses Penanaman Karakter Cinta Tanah Air Bagi Anak Usia Dini Di Sekolah Dasar, yaitu: proses pembelajaran interaksi antara siswa dan guru terbangun suasana menyenangkan, fleksibiltas guru dalam menyampaikan materi menyesuaikan dengan emosi peserta didik, hubungan keakraban dan persahabatan sebagaimana teman sendiri, dan guru memberikan kebabasan berexspresi kepada perserta didik pada saat proses pembelajaran. 


\section{DAFTAR PUSTAKA}

Aunurrahman. Belajar dan Pembelajaran. Bandung: Alfabeta, 2012.

Baharuddin. Pendidikan dan Psikologi Perkembangan. Yogyakarta: Ar-Ruz, 2009.

Bobby De Porter dan Mike Hernacki. Quantum Learning: Membiasakan Belajar Nyaman dan Menyenangkan, terj. Alwiyah Abdurrahman, Bandung: Kaifa, 2002.

Hamruni. Edutainment dalam Pendidikan Islam dan Teori-teori Pembelajaran Quantum. Yogyakarta: Fakultas Tarbiyah UIN Sunan Kalijaga, 2009.

Hamruni. Strategi dan Model-model Pembelajaran Aktif dan Menyenangkan. Yogyakarta: Fakultas Tarbiyah Universitas Islam Negeri (UIN) Sunan Kalijaga, 2009.

http://cakheppy.wordperss.com/2011/04/09/metode-edutainment/. http://gurupkn.wordpress.com/2008/04/27/paradigma-baru-dalampendidikan-dan- pembela jaran-learning-is-fun/.

Indrawati dan Wawan Setiawan. Pembelajaran Aktif, Kreatif, Efektif dan Menyenangkan, Untuk Guru SD (pdf). Jakarta: PPPPTK IPA, 2009.

Moleong, Lexy. Metodologi Penelitian Kualitatif. Bandung: Remaja Rosda Karya, 2004.

Rahman, Arief. "Edutainment sebagai Sarana Pendukung Pendidikan Berbasis Kompetensi" pada tanggal 27 Mei 2009.

Sagala, Syaiful. Kemampuan Professional Guru Dan Kependidikan. Bandung: Alfabeta, 2009.

Sardiman, A.M. Interaksi dan Motivasi Belajar Mengajar, cet. III. Jakarta: Rajawali Pers, 1990. 
Sekar D A, Savitri W dan M Kanzunnudin. Implementasi Pembelajaran Berbasis Ethno-Edutainment Untuk Meningkatkan Karakter Cinta Tanah Air Siswa Sekolah Dasar. Jurnal Ilmiah Kependidikan, Vol. 9, No. 2, 2019.

Suyono. Implementasi Belajar dan Pembelajaran. Bandung: Rosda karya, 2015.

Tohirin MS, Psikologi Pembelajaran Pendidikan Agama Islam. Jakarta: PT Raja Grafindo Persada, 2015.

www.batikyogya.wordpress.com diakses pada tanggal 07 Januari 2020.

Yusuf, Syamsul. Psikologi Perkembangan Anak dan Remaja. Bandung: Rosda, 2014. 